Vylet’al, P., \& Jankových, V. (2011). Zachycení a využití vztahů ve školní třídě sekundárního školství. In T. Janík, P. Knecht, \& S. Šebestová (Eds.), Smíšený design v pedagogickém výzkumu: Sborník príspěvkủ z 19. výročni konference České asociace pedagogického výzkumu (s. 388-392). Brno: Masarykova univerzita.

Dostupné z: http://www.ped.muni.cz/capv2011/sbornikprispevku/vyletaljankovych.pdf

doi: 10.5817/PdF.P210-CAPV-2012-85

\title{
Zachycení a využití vztahů ve školní tř́ídě sekundárního školství
}

The capture and use of relationships in the secondary education classroom

Pavel Vylet'al, Vladislav Jankových

\begin{abstract}
Abstrakt: Př́íspěvek se zabývá možnostmi smíšeného designu v pedagogickém výzkumu školní třídy jako dynamické sociální skupiny $\mathrm{v}$ rámci sekundárního školství. Zkoumá omezenost možností využití sociogramu při stanovení pozic a rolí jedinců v sociální skupině reprezentované školní třídou. Zabývá se možností rozšsiřrení šetření pomocí kvalitativní metody (pohovoru), za účelem přiblížení interpersonálních specifik sociálních vazeb zachycených sociogramem. Př́spěvek je věnován novějšímu přístupu vytváření podmínek pro partnersko-kooperativní spolupráci mezi žáky a k aktivizaci vyčleněných jedinců ve školní tř́dě. Empirická část seznamuje s výsledky předvýzkumu provedeného na 12 mužských respondentech (studentech 1. ročníku střední odborné školy). Předvýzkum pracuje s kvantitativním vyhodnocením dat zjištěných sociogramem. Závěr shrnuje teoretická a metodologická východiska smíšeného designu v pedagogickém výzkumu zaměřeném na podporu rozvoje partnersko-kooperativních kompetencí žáků.
\end{abstract}

Klíčová slova: smíšený design, školní třída, sociogram, pohovor, sociální vazby

\begin{abstract}
The paper deals with the possibilities of mixed design in educational research of a classroom as a dynamic social group in secondary education. It explores limitations of the possibility of using sociogram in determining the positions and roles of individuals in a social group represented by members of classroom. It deals with the possibility of extending investigations using qualitative methods (interview) in order to zoom in interpersonal specifics of social bonds captured by sociogram. The paper is devoted to the newer approach of creating conditions for partnership-cooperative collaboration between students and the activation of dedicated individuals in the classroom. The empirical part introduces the results of pre-research conducted on 12 male respondents (first year students of a secondary vocational school). Pre-research works with a quantitative evaluation of the data gathered by sociogram. The conclusion summarizes the theoretical and methodological bases of mixed design in educational research to support the development of partnership-cooperative competencies of students.
\end{abstract}

Keywords: mixed design, classroom, sociogram, interview, social ties

\section{1 Úvod}

Příspěvek se pokouší o implementaci moderního pojetí tzv. smíšeného výzkumu (pro který se užívá synonyma „smíšený výzkumný design“) do pedagogického výzkumu školní třídy jako dynamické sociální skupiny. S ohledem na interakční pojetí výuky je důležitým hlediskem pro učitele nejenom znalost kvantitativních znaků, ale zejména jejich kvalitativního vyjádření, které ovlivňují vnitřní strukturu (atmosféru - klima) ve třídě. Proto je důležité provádět diagnostiku vztahů, které tvoří tzv. vztahovou sít', která má velmi silnou vazbu na samotný edukační proces a jeho dosah. 


\section{Cíle př́íspěvku}

V kontextu uvedeného si můžeme položit následující otázku: „Jaké jsou možné přístupy učitele $\mathrm{k}$ vytváření podmínek pro partnersko-kooperativní spolupráci mezi žáky a $\mathrm{k}$ aktivizaci vyčleněných jedinců ve školní třídě?“، Grzelak (1992 in Nakonečný, 2009) kooperaci chápe jako chování, jež zúčastněným stranám přináší největší míru společenského zisku. Př́spěvek se pokusí o určitý vhled do problematiky a o určitý nástin odpovědi.

\section{Materiál a metody}

Deutsch (1973) rozlišuje v partnerské interakci tři postoje: partnersko-kooperativní, individualistický a konkurenční. Výchozím a stěžejním bodem charakterizující oblast př́istupu k výchově a vzdělávání jedince (trrídy) v současných podmínkách je tzv. partnerskokooperativní spolupráce, která se obecně vymezuje interakčním přístupem, vytvářením podmínek pro skupinovou spolupráci, posilování soudržnosti tř́ídy, podněcováním k vzájemnému pozitivnímu posilování, atd. Autoři $\mathrm{v}$ kontextu uvedeného a na základě soustředění získaných empirických dat a seznámení se s problematikou z praxe, kdy provedou praktický výzkum za pomoci kvantitativní techniky - sociogramu (sestávající z odpovědí na pozitivní a negativní otázku) a kvalitativní techniky - polostandardizovaného rozhovoru (tvořícího otevřené otázky dávající možnost volné výpovědi), které obklopují zkoumanou oblast (edukační proces) a její subjekty (tj. studenty), dojde k vyprofilování odpovědi, na výše položenou zadanou otázku.

Kvantitativní technika byla použita $\mathrm{v}$ rámci předvýzkumu $(\mathrm{n}=12)$, respondenty byli studenti prvního ročníku středního odborného učiliště v Jihomoravském kraji. Všichni respondenti byli mužského pohlaví ve věku 15-16 let. Výzkumným záměrem je využití kvalitativní techniky pro upřesnění vazeb ve vztahové síti zachycených předvýzkumem. Prováděné empirické šetření je prováděno za pomoci tzv. mixed-method designu (Složilová, 2011), který aplikuje pro určitou část výzkumu kvantitativní př́istup a pro další část přístup kvalitativní.

\section{Očekávané výsledky a diskuze}

\subsection{Kladný status respondentů}

V první části sociogramu respondenti odpovídali na otázku: „Vedle koho bys chtěl/a sedět v autobuse cestou na školní výlet?“،, přičemž bylo možno označit až 3 ze svých aktuálních spolužáků. Tabulka 1 ukazuje volby jednotlivých respondentů.

\subsection{Záporný status respondenti̊}

Ve druhé části sociogramu respondenti odpovídali na otázku: „Vedle koho bys nechtěl/a sedět v autobuse cestou na školní výlet?“, přičemž bylo možno označit až 3 ze svých aktuálních spolužáků. Tabulka 2 ukazuje volby jednotlivých respondentů. Na základě kvantitativního zpracování bylo následně zpracováno skóre kladného statusu osoby (viz tabulka 3). 
Tabulka 1

Pozitivní volby v sociogramu

\begin{tabular}{|c|c|c|c|c|c|c|c|c|c|c|c|c|c|c|}
\hline Žák & $\mathrm{A}$ & B & $\mathrm{C}$ & D & $\mathrm{E}$ & F & & $\mathrm{G}$ & $\mathrm{H}$ & I & $\mathbf{J}$ & K & $\mathrm{L}$ & $\begin{array}{l}\text { kolikrát } \\
\text { zvolen }\end{array}$ \\
\hline A & & 1 & & & & & & 1 & & & 1 & & & 3 \\
\hline B & & & 1 & & & & & & & & & & & 1 \\
\hline $\mathrm{C}$ & & & & 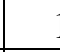 & & & & & & & & & & 1 \\
\hline D & & & 1 & & & & & & & 1 & & & & 2 \\
\hline $\mathrm{E}$ & & 1 & & & & & & & & & & & 1 & 2 \\
\hline F & & & & & & & & & 1 & & & & & 1 \\
\hline G & & & & & & & & & & & & & & 0 \\
\hline $\mathrm{H}$ & & 1 & & & & & 1 & & & & & & & 2 \\
\hline I & & & & & & & & & & & & 1 & & 1 \\
\hline J & 1 & & & & & & & & & & & 1 & & 2 \\
\hline K & & & & 1 & & & & & & 1 & 1 & & & 3 \\
\hline $\mathrm{L}$ & & & & & & & & & & 1 & & & & 1 \\
\hline $\begin{array}{l}\text { kolikrát } \\
\text { volil }\end{array}$ & 1 & 3 & 2 & 2 & & & 1 & 1 & 1 & 3 & 2 & 2 & 1 & \\
\hline
\end{tabular}

Pozn. Písmeny A až L jsou označeni jednotlivý respondenti. Zdroj: Vlastní data.

Tabulka 2

Negativní volby v sociogramu

\begin{tabular}{|l|r|r|l|l|l|l|l|l|l|l|l|l|r|}
\hline Ž́a & A & B & C & D & E & F & G & H & I & J & K & L & $\begin{array}{l}\text { kolikrát } \\
\text { Zvolen }\end{array}$ \\
\hline A & & & & & & & & & & & & & 0 \\
\hline B & & & & -1 & & & & & & & -1 & & -2 \\
\hline C & & & & & -1 & & & & & & & & 0 \\
\hline D & & & & & & & & & & & & & 0 \\
\hline E & & & & & & & & & & & & & -3 \\
\hline F & & & & & & & & & & & & & 0 \\
\hline G & & -1 & -1 & & & & & -1 & & & & & 0 \\
\hline H & & & & & & & & & & & & & 0 \\
\hline I & & & & & & & & -1 & & -1 & & & 0 \\
\hline J & & & & & & & & & & & & & \\
\hline K & & & & & & & & & & & & & \\
\hline L & & & & & & & & & & & & & \\
\hline $\begin{array}{l}\text { kolikrát } \\
\text { volil }\end{array}$ & & & & & & & & & & & & & \\
\hline
\end{tabular}

Pozn. Písmeny A až L jsou označeni jednotlivý respondenti. Zdroj: Vlastní data. 


\subsection{Pozice respondentů v rámci sociální skupiny}

$\mathrm{Na}$ základě získaných pozitivních voleb jednotlivých respondentů $(\mathrm{n}=12)$ v sociogramu (Tabulka 1) byl spočítán kladný status osoby pomocí vzorce: $\mathrm{s}^{+}=($celkový počet obdržených kladných voleb)/(n-1), uvedený v Tabulce 3. Na základě získaných záporných voleb jednotlivých respondentů $(n=12)$ v sociogramu (viz tabulka 2) byl spočítán záporný status osoby pomocí vzorce: $\mathrm{s}^{-}=$(celkový počet obdržených záporných voleb)/(n-1), uvedený v Tabulce 3. Součtem kladného a záporného statusu osoby byl vyjádřen smíšený sociometrický status jednotlivých respondentů (tabulka 3).

Tabulka 3

\section{Vyhodnocení pozic ve skupině}

\begin{tabular}{|c|c|c|c|c|c|c|c|c|}
\hline Žák & $\begin{array}{l}\text { kolikrát } \\
\text { kladně } \\
\text { zvolen }\end{array}$ & $\begin{array}{l}\text { kolikrát } \\
\text { záporně } \\
\text { zvolen }\end{array}$ & $\begin{array}{l}\text { kolikrát } \\
\text { kladně } \\
\text { volil }\end{array}$ & $\begin{array}{l}\text { kolikrát } \\
\text { záporně } \\
\text { volil }\end{array}$ & $\begin{array}{l}\text { "+" } \\
\text { kladný } \\
\text { status } \\
\text { osoby }\end{array}$ & $\begin{array}{l}\text { "-" } \\
\text { záporný } \\
\text { status } \\
\text { osoby } \\
\end{array}$ & $\begin{array}{l}\text { smíšený } \\
\text { sociometrický } \\
\text { status }\end{array}$ & $\begin{array}{l}\text { Pozice ve } \\
\text { skupině }\end{array}$ \\
\hline A & 3 & & & 0 & 0,27 & 0,00 & 0,27 & hvězda \\
\hline $\mathrm{B}$ & & -2 & & -1 & 0,09 & $-0,18$ & $-0,09$ & outsider \\
\hline $\mathrm{C}$ & & - & & -1 & 0,09 & $-0,09$ & 0,00 & pěšák \\
\hline $\mathrm{D}$ & 2 & & & -1 & 0,18 & 0,00 & 0,18 & pěšák \\
\hline $\mathrm{E}$ & 2 & & & -1 & 0,18 & 0,00 & 0,18 & pěšák \\
\hline$F$ & & & & 0 & 0,09 & 0,00 & 0,09 & pěšák \\
\hline G & ( & - & & 0 & 0,00 & $-0,27$ & $-0,27$ & zavržený \\
\hline $\mathrm{H}$ & 2 & & & -2 & 0,18 & 0,00 & 0,18 & pěšák \\
\hline I & & -2 & & 0 & 0,09 & $-0,18$ & $-0,09$ & $\begin{array}{l}\text { outsider } \\
\text { šedá }\end{array}$ \\
\hline $\mathrm{J}$ & 2 & & & -1 & 0,18 & 0,00 & 0,18 & eminence \\
\hline $\mathrm{K}$ & 3 & & & -1 & 0,27 & 0,00 & 0,27 & hvězda \\
\hline $\mathrm{L}$ & 1 & & & 0 & 0,09 & 0,00 & 0,09 & pěšák \\
\hline
\end{tabular}

Pozn. Písmeny A až L jsou označeni jednotlivý respondenti. Zdroj: Vlastní data.

Na základě uvedených hodnot, v kombinaci s údajem o tom, kolikrát daný jedinec sám pozitivně nebo negativně hodnotil ostatní jedince ze skupiny, jsme stanovili jednotlivé pozice ve skupině ( $2 \mathrm{x}$ hvězda, $1 \mathrm{x}$ šedá eminence, $6 \mathrm{x}$ pěšák, $2 \mathrm{x}$ outsider, $1 \mathrm{x}$ zavržený), uvedené v Tabulce 3. Čáp a Mareš (2007) se domnívají, že dobré zařazení do skupiny, které je opakem izolovanosti, nebo dokonce zavrženosti skupinou, přináší členovi skupiny uspokojení, podporuje jeho sebehodnocení a zvyšuje jeho pocit jistoty. Dobré zařazení do skupiny je důležitým motivačním činitelem $\mathrm{v}$ rámci partnerské kooperace uvnitř skupiny.

\section{Závěr}

Odpověd’ na otázku: „Jaké jsou možné přístupy učitele k vytváření podmínek pro partnerskokooperativní spolupráci mezi žáky a k aktivizaci vyčleněných jedinců ve školní třídě?" je z výše uvedeného zřejmá. Lze konstatovat, že je bezpodmínečně nutné, zabývat se v rámci smíšeného výzkumu nejen zachycováním kvantitativních znaků, ale také znaků kvalitativních.

Jestliže učitel přistoupí vážně $\mathrm{k}$ realizaci aktivit $\mathrm{v}$ rámci partnersko-kooperativní spolupráce, musí sledovat zájmy všech zúčastněných jedinců. K realizaci tohoto cíle lze využít vazeb 
zachycených sociogramem. Učitel však musí vzít v úvahu omezenost sociogramu jakožto metody zachycující pouze situaci tady a ted', avšak bez zohlednění vnitřní dynamiky třídy jakožto malé sociální skupiny. Změny související s neustálým vývojem vztahů ve školní třídě by v každém případě měly směřovat k pozitivnímu vývoji. Pro optimální dosažení výsledku je však důležité nejen chápání aktuálních vztahů ve školní třídě, ale především jejich hlubších souvislostí, které nelze chápat pouze na základě kvantitativních hodnot.

Výzkumným záměrem autorů v rámci navazujícího výzkumu je využití kvalitativní techniky rozhovoru pro upřesnění vazeb ve vztahové síti zachycených sociogramem. V souvislosti s tím je neméně důležitá interpretace výsledků zachycených rozhovorem, která povede $\mathrm{k}$ usměrňování dalších, následných rozhodovacích procesů spojených s uplatňováním partnersko-kooperativní spolupráce. Nakonečný (2009) popisuje kooperativní chování jako formu spolupráce, jejímž prostřednictvím se zvyšuje pravděpodobnost dosažení společného cíle. Spolupráce jedince navzájem současně sjednocuje a zavazuje.

\section{Literatura}

Čáp, J., \& Mareš, J. (2007). Psychologie pro učitele. Praha: Portál.

Deutsch, M. (1973). The resolution of conflict: constructive and destructive processes. New Haven:

Yale University Press.

Ferjenčík, J. (2010). Úvod do metodologie psychologického výzkumu. Praha: Portál.

Nakonečný, M. (2009). Sociální psychologie. Praha: Academia.

Složilová, E. (2011). Pragmatismus jako filozofický základ smíšeného výzkumného designu. Pedagogická orientace, 21(1), 51-69.

\section{Kontakt}

Mgr. Pavel Vylet'al

Mgr. Vladislav Jankových

Mendelova univerzita v Brně

Institut celoživotního vzdělávání

Zemědělská 5, 61300 Brno

e-mail: pavel.vyletal@mendelu.cz

vladislav.jankovych@mendelu.cz

\section{Bibliografické údaje}

Vylet’al, P., \& Jankových, V. (2011). Zachycení a využití vztahů ve školní třídě sekundárního školství. In T. Janík, P. Knecht, \& S. Šebestová (Eds.), Smišený design v pedagogickém výzkumu: Sborník př́spěvků z 19. výročni konference České asociace pedagogického výzkumu (s. 388-392). Brno: Masarykova univerzita.

Dostupné z: http://www.ped.muni.cz/capv2011/sbornikprispevku/vyletaljankovych.pdf doi: 10.5817/PdF.P210-CAPV-2012-85 